\title{
Poesía
}

\section{Oda a la bicicleta: Menos biciquieta}

\section{Pablo Sotoca Orgaz}

Profesor Asociado de la Universidad de Alcalá, Departamento de Ciencias de la Educación, área de Expresión Corporal. Profesor de Educación Física en ESO y FPB en Las Naves-Salesianos Alcalá. Autor correspondencia: pablo.sotoca@uah.es

Dicen que no se queja haga lluvia, sol o nieve, siempre que sea cauto la persona que la lleve.

Si llegas tarde andando te saca de algún apuro, cuídala si espera fuera, eso sí, ¡en lugar seguro!.

Hay días que está contenta si se cruza con sus primas, las plegables, con ruedines y también de rueda fina.

Le acompaña siempre un casco

y un chaleco reflectante, así la ven los de atrás y también los de delante.

Tiene miedo cuando sale a pasear por las noches, lleva la luz encendida, ¡le dan mucho miedo los coches!

Al trabajo se anima con superhéroes valientes, les despierta, mueve su cuerpo, y activa también su mente. 
Si su dueño es deportista

la lleva a ver el monte, ¡vaya vistas desde arriba

mire al sur o mire al norte!

Que orgullosa está en mi casa

mi querida bicicleta,

ha conocido medio mundo, nunca la dejaré quieta.

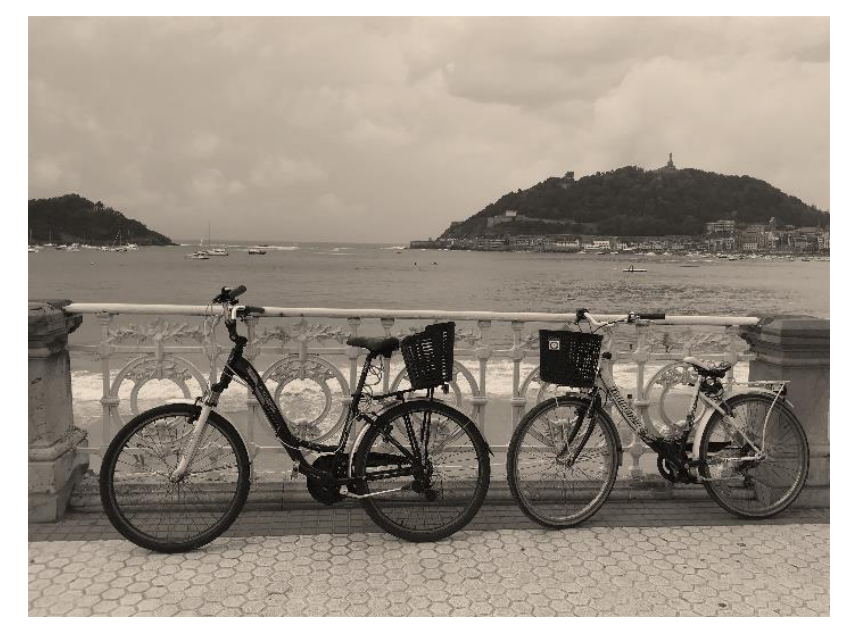

Sotoca, P. (2018). Playa de la Concha/Donosti, España.

Inspiración en la obra "Oda a la bicicleta" del poeta Pablo Neruda, incluída en el Tercer libro de las Odas (1957), en el $115^{\circ}$ aniversario de su nacimiento.

\section{Dedicatoria}

A todos los docentes que acuden en bicicleta a sus centros educativos, siendo ejemplo para escolares y adolescentes.

(C) 2019 por los autores; Esta obra está sujeta a la licencia de Reconocimiento 4.0

Internacional de Creative Commons. Para ver una copia de esta licencia, visite http://creativecommons.org/licenses/by-nc-nd/4.0/. 